\title{
Correlation between meteorological changes and primary spontaneous pneumothorax: Myth or fact?
}

\author{
Meteorolojik değişiklikler ve primer spontan pnömotoraks arasındaki ilişki: \\ Efsane mi gerçek mi?
}

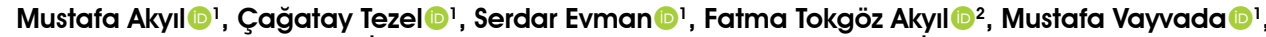

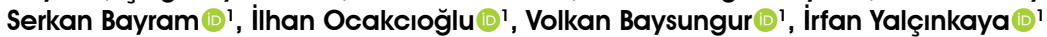

'Department of Thoracic Surgery, Süreyyapașa Chest Diseases and Thoracic Surgery Training and Research Hospital, ìstanbul, Turkey ${ }^{2}$ Department of Chest Diseases, Süreyyapaşa Chest Diseases and Thoracic Surgery Training and Research Hospital, İstanbul, Turkey
\end{abstract}

\begin{abstract}
Background: This study aims to investigate the relationship between meteorological changes and the development of primary spontaneous pneumothorax.

Methods: Medical records of 1,097 patients (975 males, 122 females; mean age $23.5 \pm 4.2$ years; range, 17 to 32 years) admitted to our hospital with a diagnosis of primary spontaneous pneumothorax between January 2010 and January 2014 were evaluated retrospectively. Daily mean values for air temperature, wind speed, humidity rate and atmospheric pressure values obtained from the local meteorological observatory were recorded. The four-year study period was separated into two groups as days with at least one primary spontaneous pneumothorax development (group 1) and days without any primary spontaneous pneumothorax development (group 2).

Results: Within the study period of a total of 1,461 days, 1,097 cases were recorded in 759 days during which primary spontaneous pneumothorax was observed. Eighty-nine percent of the patients were male. There was no significant difference between the groups in terms of mean air temperature, humidity rate, and wind speed. Atmospheric pressure was significantly lower in group $1(\mathrm{p}<0.001)$. Decrease in atmospheric pressure with respect to the previous day increased the risk of primary spontaneous pneumothorax development significantly $(\mathrm{p}<0.001)$.

Conclusion: In our study, low atmospheric pressure and significant pressure decreases showed a strong correlation with primary spontaneous pneumothorax. Temperature, wind speed, and humidity values did not influence primary spontaneous pneumothorax development.
\end{abstract}

Keywords: Atmospheric pressure; meteorology; pneumothorax.
$\ddot{O} Z$

Amaç: $\mathrm{Bu}$ çalışmada, meteorolojik değişiklikler ile primer spontan pnömotoraks gelişimi arasındaki ilişki araştırıldı.

Çalışma planı: Ocak 2010 - Ocak 2014 tarihleri arasında primer spontan pnömotoraks tanısı ile hastanemize başvuran 1097 hastanın (975 erkek, 122 kadın; ort. yaş $23.5 \pm 4.2$ yıl; dağılım, 17-32 yıl) tıbbi kayıtları geriye dönük olarak incelendi. Yerel meteoroloji gözlemevinden elde edilen hava sıcaklığı, rüzgar hızı, nem oranı ve atmosfer basıncı değerleri için günlük ortalama değerler kaydedildi. Dört yıllık çalışma periyodu en az bir primer spontan pnömotoraks gelişen (grup 1) ve primer spontan pnömotoraks gelişmeyen günler (grup 2) olmak üzere iki gruba ayrıldı.

Bulgular: Toplam 1461 günlük çalışma döneminde, primer spontan pnömotoraks gözlenen 759 gün içinde 1097 olgu kaydedildi. Hastaların \%89'u erkekti. Gruplar arasında ortalama hava sıcaklı̆̆ı, nem oranı ve rüzgar hızı açısından anlamlı farklılık yoktu. Atmosfer basıncı grup 1'de anlamlı olarak daha düşüktü $(\mathrm{p}<0.001)$. Bir önceki güne göre atmosfer basıncında azalma primer spontan pnömotoraks gelişimi riskini anlamlı ölçüde $\operatorname{artırd}_{1}(\mathrm{p}<0.001)$.

Sonuç: Çalışmamızda, düşük atmosfer basıncı ve önemli basınç azalmaları primer spontan pnömotoraks ile güçlü bir ilişki gösterdi. Sıcaklık, rüzgar hızı ve nem değerleri primer spontan pnömotoraks gelişimini etkilemedi.

Anahtar sözcükler: Atmosfer basınc1; meteoroloji; pnömotoraks.

Received: November 03, 2017 Accepted: January 16, 2018

Correspondence: Çağatay Tezel, MD. Süreyyapaşa Göğüs Hastalıkları ve Göğüs Cerrahisi Eğitim ve Araştırma Hastanesi, Göğüs Cerrahisi Kliniği, 34854 Maltepe, İstanbul, Turkey. Tel: +90 216-421 4200 e-mail: cagataytezel@hotmail.com 
It is accepted that primary spontaneous pneumothorax (PSP) develops as a result of rupture of the bullae and blebs adjacent to visceral pleura. Asthenic body type, smoking, and younger age are among the most commonly accepted risk factors. ${ }^{[1,2]}$ There is no consensus on the other related factors of PSP occurrence. Many studies have investigated the role of meteorological conditions on the development of PSP. $^{[2-8]}$ Air temperature and atmospheric pressure (AP) have been the most frequently reported factors to affect PSP occurrence. An abnormal AP change has been recorded in three out of four of patients with PSP. ${ }^{[2]}$ A 10-hectopascal (hPa) decrease in AP has been reported to increase the possibility of PSP. ${ }^{[6]}$ However, no correlation between AP and PSP has been found in other studies ${ }^{[4]}$ In terms of temperature, less frequent relationship has been reported. High temperature has been shown to increase PSP. ${ }^{[4,8]}$ In this study, we aimed to investigate the relationship between meteorological changes and the development of PSP.

\section{PATIENTS AND METHODS}

\section{Patients and meteorological data}

This retrospective observational study was carried out in Süreyyapaşa Chest Diseases and Thoracic Surgery Training and Research Hospital located in one of the most crowded cities in the world. A total of 1,097 patients (975 males, 122 females; mean age $23.5 \pm 4.2$ years; range, 17 to 32 years) with a diagnosis of PSP between January 2010 and January 2014 (for four years [1,461 days]) were included. Daily mean values of air temperature $\left({ }^{\circ} \mathrm{C}\right)$, wind speed $(\mathrm{km} /$ hour$)$, humidity rate $(\%)$ and $\mathrm{AP}$ values $(\mathrm{hPa})$ were provided from national meteorological agency. The values obtained from two airports within the city limits were recorded, and the average of the two values for each parameter was accepted as city's daily weather data. The daily changes of the variables from the previous day were coded as decrease, increase or stable. The data were also calculated as absolute value. The study protocol was approved by the Süreyyapaşa Chest Diseases and Thoracic Surgery Training and Research Hospital Ethics Committee. The study was conducted in accordance with the principles of the Declaration of Helsinki.

The study period was categorized into two groups as days with at least one PSP onset (group 1) and days without PSP onset (group 2), and the effect of the meteorological variables on PSP development was investigated. Also, the relationship between AP and the number of admitted cases per day was investigated.

\section{Statistical analysis}

Statistical Package for Social Sciences (SPSS) for Windows, version 16.0 (SPSS Inc., Chicago, IL, USA) software was used for the statistical analysis. Data were given as the mean \pm standard deviation. Independent sample t-test was used for the comparison of averages and chi-square test was used for the categorical variables. The correlation between AP and number of admitted cases was evaluated using Pearson correlation analysis. A $p$ value $<0.05$ was accepted as statistically significant.

\section{RESULTS}

The most frequent symptom was sudden chest pain (87\%). Most frequent applications were recorded in the month of October $(n=131,12 \%)$ and the least in December $(n=41,3.7 \%)$ (Figure 1). Autumn was the most frequent season for hospital admission $(n=330,30 \%)$. Patients had applied mostly in the interval between 14:00 p.m. and 15:00 p.m. ( $\mathrm{n}=131,12 \%)$.

All 1,097 patients were recorded in 759 different days and those days were grouped as group 1. Single PSP patient applied on 501 days (66\%) in group 1 and more than one patient (two to five) applied on the rest of the 258 days (24\%). There were no PSP admittance in the other 702 days of the study period and they were named as group 2 .

The mean values of group 1 were: air temperature $16.1 \pm 8.1{ }^{\circ} \mathrm{C}$, wind speed $14.8 \pm 6 \mathrm{~km} /$ hour, humidity $67.4 \pm 10.8 \%$ and AP $1007.5 \pm 6.2 \mathrm{hPa}$. When compared to group 2 , the only statistically significant difference was for AP $(p<0.001)$. On $65 \%$ of the days in group 1 , AP decreased compared to the previous day; whereas it decreased in $35 \%$ of the days in group $2(\mathrm{p}<0.001)$. However, the absolute value of the change showed no significant difference between the groups $(p=0.868)$. There was no significant difference between the groups regarding air temperature $(\mathrm{p}=0.842)$, wind speed $(\mathrm{p}=0.717)$, humidity $(\mathrm{p}=0.173)$, or the difference of these variables from the previous day (Table 1).

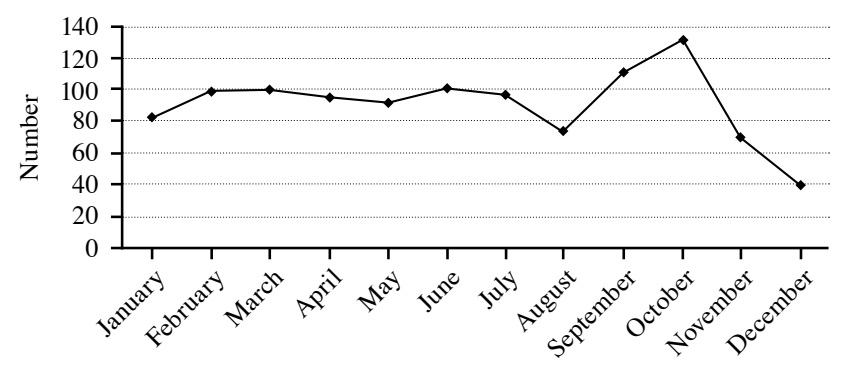

Figure 1. Admitted cases of primary spontaneous pneumothorax according to months (in four years). 
Table 1. Comparison of meteorological factors on days with or without primary spontaneous pneumothorax

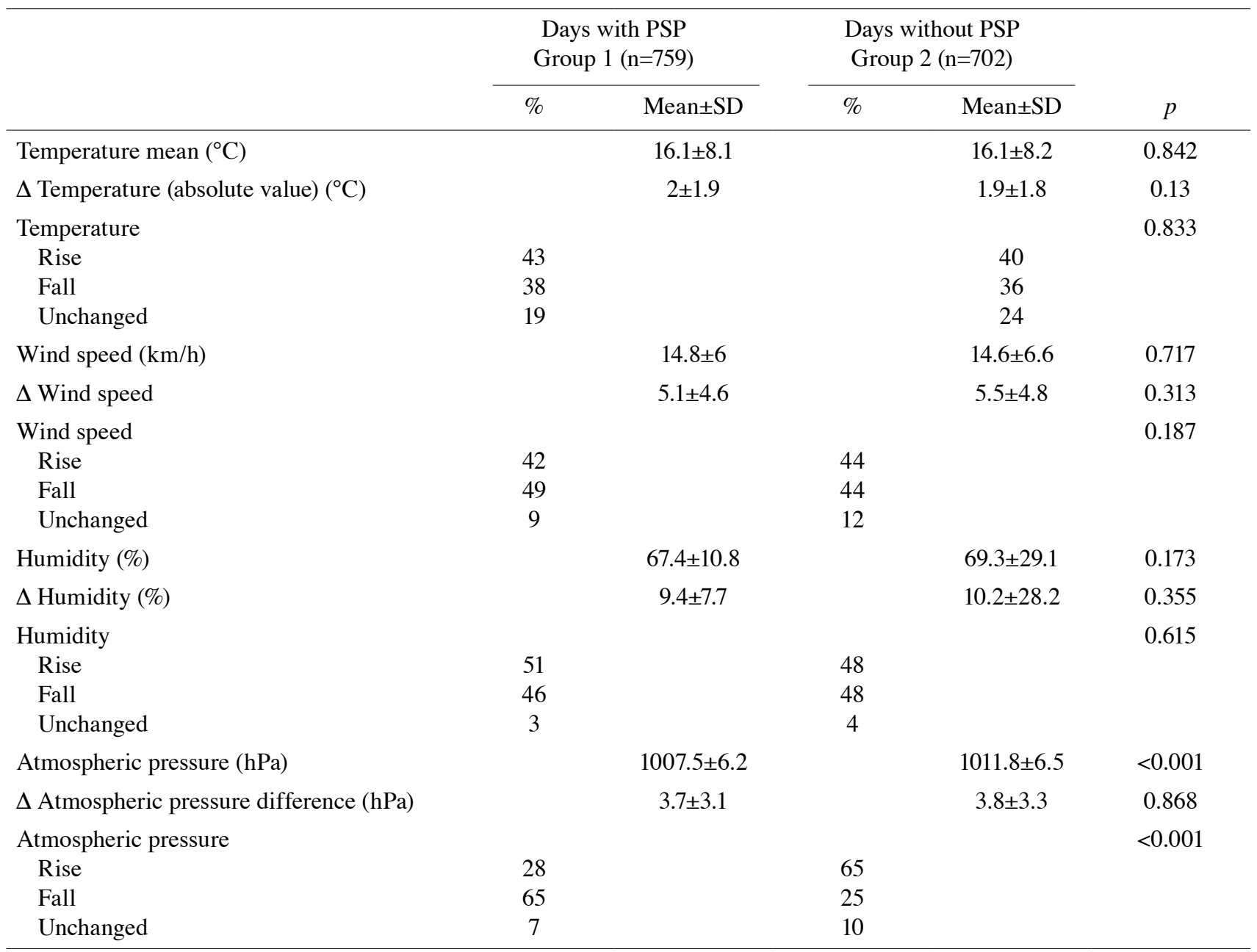

PSP: Primary spontaneous pneumothorax.

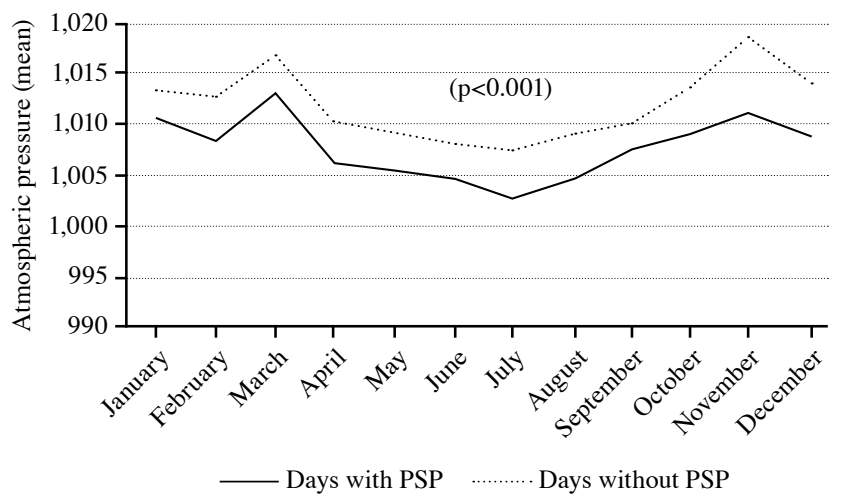

Figure 2. Mean atmospheric pressure for days with or without primary spontaneous pneumothorax according to months. PSP: Primary spontaneous pneumothorax.
Atmospheric pressure average values/months are shown in Figure 2. Daily AP did not affect daily PSP case frequency $(\mathrm{p}=0.193)$.

\section{DISCUSSION}

In the present study, PSP development has been found to be significantly related to days with low levels of AP and decreased AP compared to the previous day. No such significance has been established related to other meteorological variables. To the author's knowledge, this study presents the largest series research on the causality between meteorology and PSP development. The hospital where the study has been conducted is located in a city with a population of more than 
15 million and is the reference hospital with the highest bed capacity. Our center treats not only patients who self-apply but also those referred to us from around the city with a diagnosis of PSP and it has thoracic surgery specialists at its disposal for 24 hours and seven days. Besides such large-scale coverage of geography and demography, our study is large-scale temporally as well. In this context, the result obtained regarding the AP seems to be substantial.

Meteorological features have been linked to many disorders such as myocardial infarction, asthma and sudden hearing loss. ${ }^{[9]}$ It was reported that pneumothorax can be triggered by rapid changes in the barometric pressure during airplane flights or diving. ${ }^{[10]}$ To explain this correlation with AP, it has been suggested that there can be ruptures in the bullae, blebs or abnormal alveoli due to imbalance of pressure in the adjacent structures and rapid change of pressure and that there can be predisposition to pneumothorax due to inflammation through an asthma-like mechanism with check-valve phenomenon. ${ }^{[4]}$

A number of studies have evaluated the relationship of AP, air temperature, humidity, wind speed, and storms with pneumothorax. Bense $\mathrm{e}^{[5]}$ reported that a $10 \mathrm{hPa}$ decrease in AP within 24 hours significantly increased the number of PSP patients in two days. Scott et al. ${ }^{[2]}$ examined 192 PSP cases on exposing abnormal changes in the AP before PSP for four days. Exposure was confirmed in $72 \%$ of the cases and a correlation with pressure change was found. In a study of 337 PSP patients for three years, low AP was correlated with increased PSP risk in a statistically significant manner ${ }^{[10]}$ On the other hand, there are published series revealing no specific relationship with AP and pneumothorax development. ${ }^{[4,11]}$ In other series that evaluated both primary and secondary spontaneous pneumothorax cases, no correlation with AP was identified. ${ }^{[12-14]}$ The discrepancies in the aforementioned results point to the role of research design, climatic and the demographic circumstances where the study was conducted. Furthermore, approaching the issue by combining primary and secondary PSP cases could be a confounding factor.

A number of studies have focused on and clustered patient admittance considering that pneumothorax could have developed one day or two days before application. Formerly, the most extensive reported series was with 1,051 patients recorded for six years. In this series, PSP was recorded in $37 \%$ of the study duration and $88 \%$ of the patients fell into 597 clusters. No correlation was found with daily average AP. Only the pressure difference of the day with PSP from the previous day was found to be a significant predisposing factor. ${ }^{[15]}$ In an evaluation of 115 patients for two years in Amsterdam, $14 \%$ of the study period was recorded as pneumothorax admission days. When clustered, $73 \%$ of the cases were included in clusters ${ }^{[4]}$ In Italy, $86 \%$ of the patients remained in 76 clusters in an analysis of 294 PSP cases for four years. Atmospheric pressure difference was found to be related with PSP ${ }^{[7]}$ In a multi-center study, Özpolat et al. ${ }^{[16]}$ analyzed 669 patients admitted during a period of 10 years. Days with spontaneous pneumothorax were clustered and low AP was correlated to PSP. It was concluded that daily pressure difference and decreased AP compared to previous day increased the incidence of PSP.

In all of these studies, clustering required either a relatively low quantity of patients or a longer duration. In the present study, we could not carry out clustering because of the registration of PSP patients during more than half of the study-period. Still, the patients were mostly registered on the day their complaints commenced. It is natural that clustering has not been opted for when our status is considered as a reference center located in one of the most populous cities of the world. Either way, we believe that detecting a significant relationship with AP similar to the studies using clustering strongly evinces the correlation between AP and PSP. Our study revealed that PSP risk significantly increases with low AP. Also, daily pressure decline was detected on $65 \%$ of the days with PSP, whereas increase was detected in $65 \%$ of the other days. This finding supports our conclusion that low pressure and reductions in pressure do increase the risk.

Primary spontaneous pneumothorax frequency may be related to climatic conditions. In two previous studies from our country, PSP was found to occur mostly in autumn, and in June and November. ${ }^{[17,18]}$ Our findings revealed the highest frequency of cases in October and in autumn, as well.

High air temperature has been reported to have a correlation with PSP. ${ }^{[4,8]}$ Özpolat et al. ${ }^{[16]}$ established a correlation with low temperature; however, the authors concluded that temperature might be a cofactor in PSP risk but cannot be a factor by itself. In other studies that included air temperature analyses, no increase in PSP risk was identified..$^{[6,7,11,12,17,18]}$ In harmony with the extant literature, we did not establish any causality with temperature. No correlation between PSP and humidity or wind speed was found in our study, compatible with earlier studies. ${ }^{[8,11,12,17]}$ In another interesting study, occurrence of PSP appears to be significantly facilitated by higher and less dispersed values of daily mean nitrogen dioxide, by lower and more dispersed values 
of ozone. ${ }^{[19]}$ Abul et al. ${ }^{[20]}$ reported that spontaneous pneumothorax was more often seen in high ozone levels. We have not investigated the nitrogen dioxide and ozone concentration which showed a correlation with pneumothorax.

The main limitation of the present study is the retrospective, single-centre design. The clinical history and the clinical status of the patients could not be included. However, it has several important strengths. First of all, it was conducted in one of the most crowded cities in the world and had the largest patient sample to date. Secondly, we obtained the accurate meteorological data from the national meteorological agency. Lastly, we believe that the study period was long enough to establish accurate results.

In conclusion, primary spontaneous pneumothorax has a significant relationship with low atmospheric pressure as well as decreases in the atmospheric pressure. Air temperature, wind speed, and humidity are not correlated with primary spontaneous pneumothorax development. This conclusion is substantial particularly for emergency services as it places primary spontaneous pneumothorax probability into the portfolio of prioritized diagnoses for days with low atmospheric pressure or when a decrease in atmospheric pressure is observed.

\section{Declaration of conflicting interests}

The authors declared no conflicts of interest with respect to the authorship and/or publication of this article.

\section{Funding}

The authors received no financial support for the research and/or authorship of this article.

\section{REFERENCES}

1. MacDuff A, Arnold A, Harvey J. Management of spontaneous pneumothorax: British Thoracic Society Pleural Disease Guideline 2010. Thorax 2010;65:18-31.

2. Scott GC, Berger R, McKean HE. The role of atmospheric pressure variation in the development of spontaneous pneumothoraces. Am Rev Respir Dis 1989;139:659-62.

3. Suarez-Varel MM, Martinez-Selva MI, Llopis-Gonzalez A, Martinez-Jimeno JL, Plaza-Valia P. Spontaneous pneumothorax related with climatic characteristics in the Valencia area (Spain). Eur J Epidemiol 2000;16:193-8.

4. Smit HJ, Devillé WL, Schramel FM, Schreurs JM, Sutedja TG, Postmus PE. Atmospheric pressure changes and outdoor temperature changes in relation to spontaneous pneumothorax. Chest 1999;116:676-81.

5. Bense L. Spontaneous pneumothorax related to falls in atmospheric pressure. Eur J Respir Dis 1984;65:544-6.

6. Bulajich B, Subotich D, Mandarich D, Kljajich RV, Gajich M. Influence of atmospheric pressure, outdoor temperature, and weather phases on the onset of spontaneous pneumothorax. Ann Epidemiol 2005;15:185-90.

7. Alifano M, Forti Parri SN, Bonfanti B, Arab WA, Passini A, Boaron M, et al. Atmospheric pressure influences the risk of pneumothorax: beware of the storm! Chest 2007;131:1877-82.

8. Zhang GJ, Gao R, Fu JK, Jin X, Zhang Y, Wang Z. Climatic conditions and the onset of primary spontaneous pneumothorax: an investigation of the influence of solar terms. Med Princ Pract 2012;21:345-9.

9. Danet S, Richard F, Montaye M, Beauchant S, Lemaire B, Graux C, et al. Unhealthy effects of atmospheric temperature and pressure on the occurrence of myocardial infarction and coronary deaths. A 10-year survey: the Lille-World Health Organization MONICA project (Monitoring trends and determinants in cardiovascular disease). Circulation 1999;100:1-7.

10. Dermksian G, Lamb LE. Spontaneous pneumothorax in apparently healthy flying personnel. Ann Intern Med 1959;51:39-51.

11. Carrido García JA, Cabezudo Hernández MA, Fernández Rego G, Fernández Bustillo E. Association between falls in atmospheric pressure and spontaneous pneumothorax. Eur J Respir Dis 1985;66:230.

12. Ayed AK, Bazerbashi S, Ben-Nakhi M, Chandrasekran C, Sukumar M, Al-Rowayeh A, et al. Risk factors of spontaneous pneumothorax in Kuwait. Med Princ Pract 2006;15:338-42.

13. Chen CH, Kou YR, Chen CS, Lin HC. Seasonal variation in the incidence of spontaneous pneumothorax and its association with climate: a nationwide population-based study. Respirology 2010;15:296-302.

14. Obuchi T, Miyoshi T, Miyahara S, Hamanaka W, Nakashima $\mathrm{H}$, Yanagisawa J, et al. Does pneumothorax occurrence correlate with a change in the weather? Surg Today 2011;41:1380-4.

15. Haga T, Kurihara M, Kataoka H, Ebana H. Influence of weather conditions on the onset of primary spontaneous pneumothorax: positive association with decreased atmospheric pressure. Ann Thorac Cardiovasc Surg 2013;19:212-5.

16. Ozpolat B, Gözübüyük A, Koçer B, Yazkan R, Dural $\mathrm{K}$, Genç O. Meteorological conditions related to the onset of spontaneous pneumothorax. Tohoku J Exp Med 2009;217:329-34.

17. Celik B, Kefeli Celik H, Hamzaçebi H, Demir H, Furtun $\mathrm{K}$, Ortamevzi C. The role of meteorological conditions on the development of spontaneous pneumothorax. Thorac Cardiovasc Surg 2009;57:409-12.

18. Bozkurt S, Tokur M, Okumuş M, Kahraman H, Özkan F, Tabur A. Role of meteorological changes in occurrence of spontaneous pneumothorax and clinical characteristics of patients. Turk Gogus Kalp Dama 2013;21:95-9.

19. Bertolaccini L, Alemanno L, Rocco G, Cassardo C. Air pollution, weather variations and primary spontaneous pneumothorax. J Thorac Dis 2010;2:9-15.

20. Abul Y, Karakurt S, Bostanci K, Yuksel M, Eryuksel E, Evman S, et al. Spontaneous pneumothorax and ozone levels: is there a relation? Multidiscip Respir Med 2011;6:16-9. 